\title{
Suicidal Ideation and Behaviours after Traumatic Brain Injury: A Systematic Review
}

\author{
Nazanin H. Bahraini, ${ }^{1,2}$ Grahame K. Simpson,, ${ }^{3,4}$ Lisa A. Brenner, ${ }^{1,2}$ Adam S. Hoffberg, ${ }^{1}$ \\ and Alexandra L. Schneider ${ }^{1}$ \\ ${ }^{1}$ Veterans Integrated Service Network (VISN) 19 Mental IIIness Research Education and Clinical Center \\ (MIRECC), Denver, Colorado, USA \\ ${ }^{2}$ University of Colorado, School of Medicine, Aurora, Colorado, USA \\ ${ }^{3}$ Liverpool Brain Injury Rehabilitation Unit, Liverpool Hospital, Sydney, Australia \\ ${ }^{4}$ Rehabilitation Studies Unit, Sydney School of Medicine, University of Sydney, Australia
}

Traumatic brain injury ( $\mathrm{TB} I)$ is prevalent among many populations and existing data suggest that those with TBI are at increased risk for death by suicide. This systematic review serves as an update to a previous review, with the aim of evaluating the current state of evidence regarding prevalence and risk of suicide deaths, post-TBI suicidal ideation and suicide attempts, and treatments to reduce suicide-related outcomes among TBI survivors. Review procedures followed the PRISMA statement guidelines. In all, 1014 abstracts and 83 full-text articles were reviewed to identify 16 studies meeting inclusion criteria. Risk of bias for individual studies ranged from low to high, and very few studies were designed to examine a priori hypotheses related to suicide outcomes of interest. Overall, findings from this systematic review supported an increased risk of suicide among TBI survivors compared to those with no history of TBI. Evidence pertaining to suicidal thoughts and attempts was less clear, mainly due to heterogeneity of methodological quality across studies. One small randomised controlled trial was identified that targeted suicide prevention in TBI survivors. Further research is needed to identify the prevalence of post-TBI ideation and attempts, and to establish evidence-based suicide prevention practices among TBI survivors.

Keywords: suicide, suicide attempt, suicide ideation, traumatic brain injury, systematic review

Suicide is a rare but devastating outcome post traumatic brain injury (TBI). However, death by suicide is only the tip of the iceberg, as much larger numbers of people with TBI make suicide attempts or report suicidal ideation. Historically, suicides after TBI were first documented among brain-injured Veterans from the First and Second World Wars (e.g., Russell, 1951). Early reports of civilian suicides were contained in broader TBI outcome studies conducted in the United Kingdom and Europe (e.g., Heiskanen \& Sipponen, 1970; Lewin, Marshall, \& Roberts, 1979). Since then, continued efforts to empirically investigate the prevalence of suicide and the impact of TBI on suicide risk have contributed to a growing body of literature on suicide-related outcomes among TBI survivors. Although studies examining prevalence of suicidal ideation, behaviour and death by

Address for correspondence: Nazanin H. Bahraini, VISN 19 MIRECC, 1055 Clermont Street, Denver, Colorado, 80220,USA.E-mail: Nazanin.Bahraini@va.gov

Disclaimer: This article is based on work supported, in part, by the Department of Veterans Affairs, but does not necessarily represent the views of the Department of Veterans Affairs or the United States Government. Drs Brenner and Simpson would also like to acknowledge that they are authors on 6 of the 16 papers reviewed. Efforts were made to reduce conflicts (i.e., other members of the team reviewed their articles in terms of risk of bias). 
suicide among TBI survivors have yielded variable rates, some studies have shown that, compared to the general population, those with a history of TBI are at increased risk of suicidal ideation (Anstey et al., 2004), suicide attempts (Silver, Kramer, Greenwald, \& Weissman, 2001) and death by suicide (Teasdale \& Engberg, 2001). However, not all studies have found such a relationship, with two mortality studies not reporting an elevated rate of suicide deaths (Harrison-Felix, Whiteneck, DeVivo, Hammond, \& Jha, 2006; Shavelle, Strauss, Whyte, Day, \& Yu, 2001).

The purpose of this study was to conduct a systematic review of the literature in order to evaluate the evidence regarding prevalence and risk of suicidal thoughts, behaviours and death by suicide following TBI, and to examine the effectiveness of interventions to reduce suicide-related outcomes in those with TBI. The first dedicated review addressing the prevalence of suicidal thoughts and behaviours (deaths and attempts), risk factors for suicide and clinical management approaches among survivors of TBI was published in 2007 (Simpson \& Tate, 2007). A scoping methodology was chosen to ascertain both the breadth and depth of evidence within the field. The structured review identified 48 peer-reviewed journal articles published before 2007 that addressed suicidality among survivors of TBI. This relatively large number of citations was deceptive, however, as few of the articles comprised suicide-specific studies per se. In the majority of cases, suicidal behaviours were incidental to the primary focus of the studies, which were investigating general post-injury mortality, psychosocial outcomes or depression.

Based on the most robust studies available (three population studies, one meta-analysis), the review concluded that, in comparison to the general population, individuals with TBI were at a 3.5-4 times greater risk of suicide (Harris \& Barraclough, 1997; Teasdale \& Engberg, 2001); had a significantly higher lifetime history of suicide attempts $(8.1 \%$ in TBI survivors versus $1.9 \%$ in the general population; Silver et al., 2001) and higher levels of suicidal ideation (Anstey et al., 2004). The studies into suicide attempts and suicide ideation found that the elevated rates remained significant after adjusting for a range of demographic, socio-economic, psychosocial and psychopathological covariates.

Furthermore, the 2007 review found evidence for two domains of risk factors that modulated levels of suicidal behaviours. Importantly, the following findings were all derived from multivariate analyses that controlled for covariates, including sex, age at injury, time post-injury, length of posttraumatic amnesia, pre-morbid psychiatric distur- bance and post-injury psychopathlogy. The first domain was injury severity. People with severe TBI were 1.4 times more likely to die by suicide than people with mild injuries (95\% confidence interval (CI), 1.15, 1.75; Teasdale \& Engberg, 2001). The second domain was post-injury psychopathology. Post-injury substance abuse, suicide ideation, hopelessness and/or the presence of any post-injury psychiatric history/emotional distress were significant predictors of either suicide attempts or suicide ideation (Simpson \& Tate, 2002, 2005; Teasdale $\&$ Engberg, 2001). The risk of attempts or suicidal ideation among individuals with such psychopathology was 4.9-8.7 times greater than for people with TBI and no post-injury history of psychopathology (Simpson \& Tate, 2002, 2005; Teasdale \& Engberg, 2001). The review also found that among TBI survivors, little research into suicide prevention had been conducted. No treatments or clinical management approaches for people with TBI had been tested. The only experimental report was of the outcomes from a controlled trial of a suicide prevention training programme delivered to rehabilitation and disability staff working in the field of TBI (Simpson, Winstanley, \& Bertapelle, 2003).

Overall, the review found a consistent picture of elevated suicidal behaviours after TBI, but the underlying evidence-base was limited to a small number of studies. In the introduction to a recent special issue on suicide and TBI, Simpson and Brenner (2011) observed that there had been an upsurge in research activity in this field over the previous decade. Since the original 2007 review, several narrative reviews of the suicide literature focusing on TBI among civilians and/or military Veterans have been published (Brenner, Vanderploeg, \& Terrio, 2009; Reeves \& Brister, 2009; Reeves \& Laizer, 2012; Simpson \& Tate, 2009; Wasserman et al., 2008). These reviews have canvassed much of the earlier literature, but have also highlighted a number of newer studies.

Therefore, the current review investigated literature published from the beginning of 2007. While certain aspects of the original review (i.e., risk of suicidal outcomes following TBI and clinical management of suicidal behaviours after TBI) have been preserved, the suicide nomenclature and review methodology have been updated to reflect contemporary developments. The latest standardised suicide nomenclature (the Self-Directed Violence Classification System; Brenner et al., 2011b) has been adopted, replacing the 1996 framework (O'Carroll et al., 1996) employed in the 2007 study. With respect to methodology, the current review has been conducted in accordance with relevant items from the PRISMA (Preferred Reporting 
Items for Systematic Reviews and Meta-Analyses) Statement (Liberati et al., 2009; Moher, Liberati, Tetzlaff, Altman, \& the PRISMA Group, 2010). Items included in the PRISMA statement reflect several conceptual and practical advances in the science of conducting systematic reviews (Moher et al., 2010), a number of which pertain to assessment of risk of bias.

Despite the centrality of risk of bias assessment in evaluating the strength of evidence in systematic reviews, there is little consensus on the best approach or preferred tool for assessing risk of bias. Given that the current review was designed to address multiple research questions pertaining to TBI and suicide-related outcomes, approaches and tools selected would need to take into account the heterogeneity of studies both with respect to design and study conduct. In the absence of a gold-standard tool for assessing risk of bias across different types of studies, a number of different potential tools and approaches were considered for the current review. The two tools finally selected to rate the study designs targeted in this review, namely, the Research Triangle Institute (RTI) Risk of Bias tool (Viswanathan \& Berkman, 2012) for observational studies and the PEDro rating scale (Sherrington, Herbert, Maher, \& Moseley, 2000) for randomised trials, met many of the recommended criteria for risk of bias measurement selection (Reeves, Deeks, Higgins, \& Wells, 2008; Viswanathan et al., 2012). Specifically, they were designed for use in systematic reviews; demonstrated acceptable reliability and validity; provided explicit support for judgements; were easy to use; addressed items related to different sources of bias (i.e., study level and outcome level); avoided the use of uniform weights across items (RTI Risk of Bias tool only); were specific to the study designs being evaluated; and, when possible, the risk of bias assessment was not presented as a composite score, or if a composite score was used, its validity as an overall measure of methodological quality had been established previously (e.g., PEDro rating scale; deMorton, 2009). Informed by these advances in methodology, the review addressed two key questions (KQ):

KQ1. Among adult survivors of TBI, what is the association between history of TBI and post-TBI death by suicide, suicide attempts or suicidal ideation? KQ1 specifically investigated the prevalence of the suicidal behaviours (i.e., death by suicide, suicide attempts and suicidal ideation) and the extent to which the presence of TBI increased risk for suicidal thoughts and behaviours.
KQ2. What interventions are effective in reducing suicide-related outcomes in adult survivors of TBI?

\section{Methods}

The methodology and presentation of results followed the PRISMA Statement for reporting systematic reviews of studies that evaluate healthcare interventions (Liberati et al., 2009; Moher et al., 2010). In particular, the research group used PRISMA items 1, 3-4, 6-13, 17-20 and 24-26, and the recommended study flow diagram. Items that were not included were outside the scope of the current review. For example, heterogeneity of methods, study conduct and overall study quality across the relatively small number of studies identified for each key question precluded quantitative synthesis of results. As such, items 14-16 and 2123 were not reported as they pertain to summary statistics and meta-analyses. Following study selection and data extraction, risk of bias of each outcome of interest within individual studies was assessed and incorporated in a qualitative synthesis of findings from all studies for each key question and outcome.

\section{Search Strategy}

PubMed, PsycINFO, EMBASE and the Cochrane Central Register of Controlled Trials (Central) were searched on 1 October 2012 for peerreviewed articles published in English from 1 January 2007 through 1 October 2012 to gather relevant articles to address the aims examined in the key research questions listed above. Terms relating to suicide and self-directed violence were crossed with terms related to traumatic brain injury (see Table 1). Prior to the search strategy being finalised, preliminary searches across all databases were conducted that included additional self-harm terms from the National Institute for Health and Clinical Excellence (NICE) commissioned report on self-harm (NICE, 2012). Searches were also conducted using additional brain injury terms from the World Health Organisation (WHO) report on mild traumatic brain injury (mTBI) (Carroll, Cassidy, Holm, Kraus, \& Coronado, 2004). After running the preliminary searches with these additional terms and browsing the results, it was determined by unanimous consensus within the research group that while highly sensitive, the search yield was not specific enough for the purposes of this review. For example, the vast majority of studies that were identified were not specific to TBI, but instead covered a wide range of physical injuries and illnesses throughout the body. Based on these issues, the 
TABLE 1

PubMed Search Strategy

\begin{tabular}{|c|c|c|}
\hline $\begin{array}{l}\text { Search } \\
\text { number }\end{array}$ & Search term & Database results \\
\hline (1) & suicide $[\mathrm{MeSH}]$ & 44,091 \\
\hline (2) & suicide, attempted $[\mathrm{MeSH}]$ & 13,743 \\
\hline (3) & $\begin{array}{l}\text { suicid" OR "attempted suicide" OR "suicide prevention" OR "suicide risk" OR } \\
\text { suicid* self-regulation OR "suicidal ideation" OR suicid* behavior OR suicid" } \\
\text { behavior OR suicidality OR self injur* OR self-injur* OR "self harm" OR self-harm } \\
\text { OR selfharm OR parasuicid* OR deliberate self injur* OR deliberate self-injur* } \\
\text { OR "deliberate self harm" OR "deliberate self-harm" OR self directed violen* OR } \\
\text { self-directed violen* }\end{array}$ & $\begin{array}{l}\text { 53,045 Field: } \\
\text { All Fields }\end{array}$ \\
\hline (4) & (\#1) OR (\#2) OR (\#3) & 53,045 \\
\hline (5) & Traumatic brain injury[MeSH] & 44,439 \\
\hline (6) & Coma $[\mathrm{MeSH}]$ & 17,025 \\
\hline (7) & Glasgow coma scale[MeSH] & 5994 \\
\hline (8) & Glasgow outcome scale $[\mathrm{MeSH}]$ & 1026 \\
\hline (9) & $\begin{array}{l}\text { traumatic brain injur* OR brain damag* OR brain injur* OR head injur* OR diffuse } \\
\text { axonal injur* OR brain fractur* OR brain trauma* }\end{array}$ & $\begin{array}{l}\text { 62,920 Field: } \\
\text { Title/Abstract }\end{array}$ \\
\hline (10) & glasgow AND (coma OR outcome) AND (scale* OR score*) & $\begin{array}{l}7926 \text { Field: } \\
\text { Title/Abstract }\end{array}$ \\
\hline (11) & "Rancho los amigos scale" & $\begin{array}{l}31 \text { Field: } \\
\text { Title/Abstract }\end{array}$ \\
\hline$(12)$ & $\begin{array}{l}\text { (coma* OR concuss* OR unconscious* OR "persistent vegetative state") AND } \\
\text { (damag* OR fractur* OR injur* OR trauma*) }\end{array}$ & $\begin{array}{l}\text { 11,271 Field: } \\
\text { Title/Abstract }\end{array}$ \\
\hline (13) & "mtbi" OR mild trauma* injur* OR minor trauma* injur* & $\begin{array}{l}1721 \text { Field: } \\
\text { Title/Abstract }\end{array}$ \\
\hline (14) & $(\# 5)$ OR (\#6) OR (\#7) OR (\#8) OR (\#9) OR (\#10) OR (\#11) OR (\#12) OR (\#13) & 106,192 \\
\hline (15) & (\#4) AND (\#14) & 934 \\
\hline (16) & Limit (\# 15) to Child & 238 \\
\hline (17) & Limit (\# 15) to Adult 19+ & 684 \\
\hline (18) & (\#16) NOT (\#17) & 68 \\
\hline (19) & (\#15) NOT (\#18) & 866 \\
\hline (20) & Limit (\#19) to published between 1/1/2007 and 9/30/2012, Human, English & 176 \\
\hline
\end{tabular}

search terms were further refined to improve detection of TBI-specific studies while filtering out studies that were focused on other types of injury.

\section{Study Selection}

Data were exported from each database and abstracted and de-duplicated using EndNote X3 (Build 4094) by a research assistant with experience working on TBI-related research studies. When identifying duplicates in EndNote, records were removed from the count of the database with the lower priority. Databases were assigned priority a priori and results were de-duplicated according to the following priority: EMBASE $>$ PubMed $>$ PsycINFO $>$ CENTRAL. Using a standardised electronic template, all abstracts were reviewed by two 'blind' reviewers (L.B. and N.B.) with exper- tise in TBI and suicide, to determine whether they met inclusion criteria. Studies were included if they were believed to have met the following study characteristics (Population, Intervention, Comparators, Outcomes, Timing, Setting).

Population(s). This review was focused on adults who experienced TBI. The 'adult' age filters were used during the literature search to target studies that included adults. For PubMed, adults were defined as age 19 and above. For PsycINFO and EMBASE, adults were defined as age 18 and above. Studies that did not differentiate between adult and child populations were excluded. A clear case definition for TBI must also have been provided.

Intervention(s). Randomised and non-randomised interventions that contribute to suicide prevention and reported a suicide-related outcome. 
Comparator(s). Similar populations that have not been diagnosed with TBI; comparison group was not required for inclusion.

Outcome(s). Suicidal ideation and/or behaviour as defined according to the Self-Directed Violence Classification System (Brenner et al., 2011b), which can be accessed at http://www.mirecc. va.gov/visn19/docs/SDVCS.pdf

Timing. No limitations based on timing.

Setting. No limitations based on study setting.

Additional criteria included: (1) the full-text article was in English; (2) the article addressed a TBI population and measured post-TBI suiciderelated outcomes (studies with samples from the general population who suffered a TBI as a result of self-inflicted injury were excluded); (3) the article presented original study data (dissertations, commentaries, editorials, letters, books/book chapters and reviews were excluded); and (4) the study used a quantitative design (qualitative studies were excluded). Although excluded, any systematic reviews and meta-analyses identified were reviewed for additional reference mining. At the abstract review level (PRISMA Screening Stage), disagreements regarding inclusion criteria were resolved by including a third reviewer for consensus.

Full-text was obtained for all articles that met the screening inclusion criteria. Each article was examined by two reviewers (three 'blind' reviewers in total taking part). If upon full-text review (PRISMA Eligibility Stage), it was determined that the article did not meet inclusion criteria (as noted above), it was excluded. Disagreements regarding the inclusion of an article at the Eligibility Stage were similarly resolved by consensus of a third reviewer. Reviewers discussed any remaining studies and ultimately reached a unanimous decision regarding the inclusion status of all articles.

Additional searches were conducted of the reference lists of all included articles, systematic reviews and meta-analyses identified in the literature search, as well as the grey literature (using Google Search and Google Scholar). For the grey literature, an advanced search was conducted searching for all of the words 'traumatic brain injury' and 'suicide'. The first 11 pages of results were reviewed for possible inclusion according to the same criteria as the database literature search. Any review articles identified in these searches were also mined for additional references.

\section{Data Abstraction}

The following data were abstracted for observational studies with prevalence of suicidal ideation
(SI), suicide attempt (SA) or both as outcome of interest: study design, sample size and setting, sample demographics (sex, age), TBI severity, source or measure of SI/SA, and time frame, time post-injury and prevalence of SI/SA. For observational studies that investigated whether the presence of TBI increased risk for SI/SA, data abstracted included additional information pertaining to analyses and results. Studies in which death was the outcome of interest abstracted the following: study design, population/sample, study admission (target period), TBI severity, reference population, prevalence of suicide, and standard mortality ratios (SMR) or odds ratios (OR). Data abstracted from treatment studies included: design, sample size and setting, sample demographics (sex, age), TBI severity, time post injury, primary outcomes, measures of SI, attrition and treatment outcome.

\section{Assessment of Risk of Bias of Observational Studies}

Procedures and tools for assessing risk of bias for observational studies were largely informed by guidelines established in the Agency for Healthcare Research and Quality methods guide for systematic reviews (Viswanathan \& Berkman, 2012; Viswanathan et al., 2012) and included the procedures described below.

Classification of Study Design. Correct classification of study design and identifying critical sources of bias and confounding for that type of design are critical to accurately assessing risk of bias (Viswanathan \& Berkman, 2012). The design for each study meeting inclusion criteria following full-text review was assessed by two independent raters using the Taxonomy of Study Design Tool (Hartling et al., 2010). Disagreements were discussed until consensus was achieved.

Risk of Bias Components Analysis. For observational studies, the RTI Risk of Bias tool (Viswanathan \& Berkman, 2012) was utilised to assess risk of bias, confounding and precision. Using a components approach, the RTI tool was specifically developed to assess risk of bias across different types of observational studies (i.e., cohort, case-control, cross-sectional and case-series). Sources of bias assessed include selection bias (e.g., differential selection of study participants, inappropriate selection of controls, inclusion/exclusion criteria inconsistently applied within or across groups), detection bias (e.g., inaccurate assessment or misclassification of exposure and outcomes, use of unreliable or poorly validated measures), performance bias (e.g., variations 
in procedures administered, protocol deviations), reporting bias (i.e., differential or incomplete reporting of outcomes and study findings), attrition bias (e.g., high or differential loss to follow-up), and confounding (e.g., failure to identify or account for important confounders through design or analysis) (Viswanathan et al., 2012). In addition to risk of bias, three additional RTI items rate the precision of findings/estimates in situations where the heterogeneity of findings prevents pooling of data. Detailed instructions for the reviewer and response options pertaining to each of the questions are provided to increase clarity, accuracy and ease of use. In addition to completing response options, reviewers are instructed to provide an explanation for their ratings, thereby increasing the transparency of the evaluation.

Although the RTI Risk of Bias tool is a new tool, its development and refinement were based on a rigorous, multiphase process that consisted of face validity testing, cognitive testing, content validity testing and inter-rater reliability testing. Specifically, inter-rater reliability of the original 40 -item measure ranged from $90 \%$ for questions concerning presentation and $88 \%$ for those concerning soundness of information, to $56 \%$ for questions concerning follow-up (Viswanathan \& Berkman, 2012). The items that had poor interrater reliability were either removed or revised to improve clarity and usefulness. Following this process, further evaluation and testing of the measure through expert consensus contributed to the refined 16-item measure used in this systematic review.

Prior to evaluating risk of bias for the individual studies, reviewers met and discussed the form to clarify specific criteria pertaining to some of the questions. Decisions were made regarding important confounding variables, measures and indicators of exposure status, and measures considered to be valid and reliable. These criteria and guidelines were added to the review form to help facilitate accuracy and reliability across reviewers.

Each observational study that met inclusion criteria following full-text review was evaluated using RTI items that reflected sources of bias specific to its study design. For example, the number of core items pertaining to each of the observational designs is as follows: case series (8), case-control (8), cohort (12) and cross-sectional (10). Each risk of bias criterion was evaluated using the appropriate criteria for that study design and for each predetermined outcome. Following completion of all items, indications of bias and precision were summarised in a table by category (e.g., selection bias, detection bias). These summary results were used to evaluate the overall risk of bias for the study for each selected outcome.
Global rating of the risk of bias. Global ratings of bias for each study were classified as low (results are valid or represent true effects), moderate (results are valid and/or represent true effect; however, study is susceptible to some bias, but not to the degree that the results would be considered invalid), high (a study with significant flaws and marked by biases of various natures that are likely to invalidate the results) or unknown (missing information which makes it difficult to judge limitations) (Viswanathan et al., 2012). Two reviewers independently assessed risk of bias (individual criteria and global rating). Disagreements were resolved through consensus and, if needed, a third researcher was consulted. As two of the authors of this review were also authors on 6 out of the 16 papers evaluated, individuals were not primarily responsible for review of the articles on which they were authors.

\section{Assessment of Risk of Bias of Randomised Trials}

The single randomised clinical trial (RCT) included in this review was independently assessed by two reviewers using the PEDro scale (Sherrington et al., 2000), an 11-item scale designed for rating methodological quality of RCTs. Reliability and validity of the scale has been established across several studies (deMorton, 2009; Macedo et al., 2010; Maher, Sherrington, Herbert, Moseley, \& Elkins, 2003). Items address various components related to the conduct of the study and sources of bias that can impact the validity of findings. These include, but are not limited to, randomisation, concealed allocation, blinding, outcome reporting and follow-up/attrition. Each satisfied item (except for item 1) contributes one point to the total PEDro score (range $=0-10$ points). A search for the trial was then performed on Psycbite (www.psycbite.com), an extensive database of cognitive, behavioural and other treatments for psychological problems resulting from acquired brain impairment (ABI) and independently rated for their methodological quality (Tate et al., 2004). Scores from the current review were compared to the Psycbite PEDro score.

Current standards listed in the PRISMA statement indicate that critical appraisal of studies should consider both study level (e.g., allocation concealment) and outcome level (e.g., reliability and validity of outcome data) sources of bias. Although the PEDro scale incorporates several items that address sources of bias with respect to study-level characteristics (e.g., randomisation, allocation, 'blinding' of therapists), the number of items that specifically assess 
outcome-measurement bias are limited and primarily focused on 'blinding' of outcome assessors. Taking this into consideration, information related to measurement bias not explicitly addressed by the PEDro scale (i.e., reliability and validity of measures used to assess exposure and outcomes) was noted and considered in conjunction with PEDro scores when determining the overall risk of bias and quality rating for the trial.

\section{Results}

\section{Study Selection}

A total of 999 titles and abstracts obtained from the electronic searches were reviewed. Fifteen additional studies were identified from other sources. Applying inclusionary/exclusionary criteria, 83 articles were reviewed (see Figure 1). Of these articles, 67 were excluded as described in Figure 1. Thirteen studies were identified for KQ1 (five deaths, eight ideation and/or attempts) and three treatment-related studies were identified for KQ2.

\section{Study Characteristics and Risk of Bias}

Individual study characteristics, indicators of bias and global ratings of bias for individual studies are presented in Tables 2-6.

\section{Synthesis of Evidence}

\section{KQ1: Death by Suicide}

Death by suicide as an outcome was reported in five studies (Table 2). The purposes of the studies varied. One study specifically examined suiciderelated mortality among military Veterans with and without TBI (Brenner, Ignacio, \& Blow, 2011c). Two studies investigated mortality among civilians with TBI and included data on cause-specific deaths, including suicide (Harrison-Felix et al., 2009; Himanen et al., 2011). Finally, two studies examined individuals with TBI who died by suicide among more broadly defined populations: (1) all suicides in a province of Finland (Mainio et al., 2007); and (2) all suicides among United States serving military (Skopp, Trofimovich, Grimes, Oetjen-Gerdes, \& Gahm, 2012). Interestingly, the rates of TBI among the general suicide deaths in both studies were very similar (Finish study 5.5\%; United States Military study, 7.3\%). Three of these studies sought to quantify the level of risk of death by suicide associated with TBI (Brenner et al., 2011c; Harrison-Felix et al., 2009; Skopp et al., 2012), while the other two were descriptive only.

Findings from two retrospective cohort studies (Brenner et al., 2011c; Harrison-Felix et al., 2009) supported an increased risk for death by sui- cide among persons with TBI, while results from one case-control study (Skopp et al., 2012) did not show a significantly higher rate of TBI among those who died by suicide. Global rating of bias for one of the cohort studies (Brenner et al., 2011c), was low, and results supported an increased risk for death by suicide among US Veterans with TBI (ranging from 1.3 to 2.0 times higher than Veterans without TBI). Harrison-Felix et al. (2009) found elevated rates of suicide among a civilian cohort of TBI patients (about three times higher than persons in the general population of similar age, sex and race). However, this study had a moderate risk of bias. Although a number of important known confounders were taken into account, presence of TBI and other health-related risk factors in the comparison group (i.e., US general population) introduced sources of selection bias and other potential confounders. Furthermore, use of national death rates as opposed to general population rates for the State of Colorado also contributed to the moderate rating as age-adjusted suicide rates in the state of Colorado are notably higher than national death rates (Centers for Disease Control and Prevention, 2012). Lastly, using a case-control design, Skopp et al. (2012) compared the profile of mild TBI, psychiatric and relationship status among all 1764 suicides that occurred among serving military in the United States from 2001 to 2009 with a matched control group. The authors did not find a significantly higher rate of mild TBI among the suicide group compared to the controls. This study also had a moderate risk of bias.

\section{KQ1: Suicide Attempts}

Two retrospective suicide-specific studies reported the prevalence of suicide attempts as an outcome (Table 3). Both studies conducted archival reviews of the files of Veterans with mixed injury severity (mild to severe) in the chronic phase of TBI (14 years, 15 years). Breshears, Brenner, Harwood and Gutierrez (2010) found that $7.1 \%$ of their sample had a post-injury history of a suicide attempt within the two-year study period, with almost half of these individuals having more than one event. Gutierrez, Brenner and Huggins (2008) identified a case series of 22 Veterans with TBI who had a post-injury history of psychiatric inpatient admissions, with a file review finding reports of suicide attempts among $27.3 \%(6 / 22)$ of the sample. Both studies were classified as having moderate risk of bias.

\section{KQ1: Suicidal Ideation}

Two retrospective single-centre studies reported on the prevalence of suicide ideation as an outcome (Table 4). Both were suicide-specific studies, addressing civilian (Tsaousides, Cantor, \& 


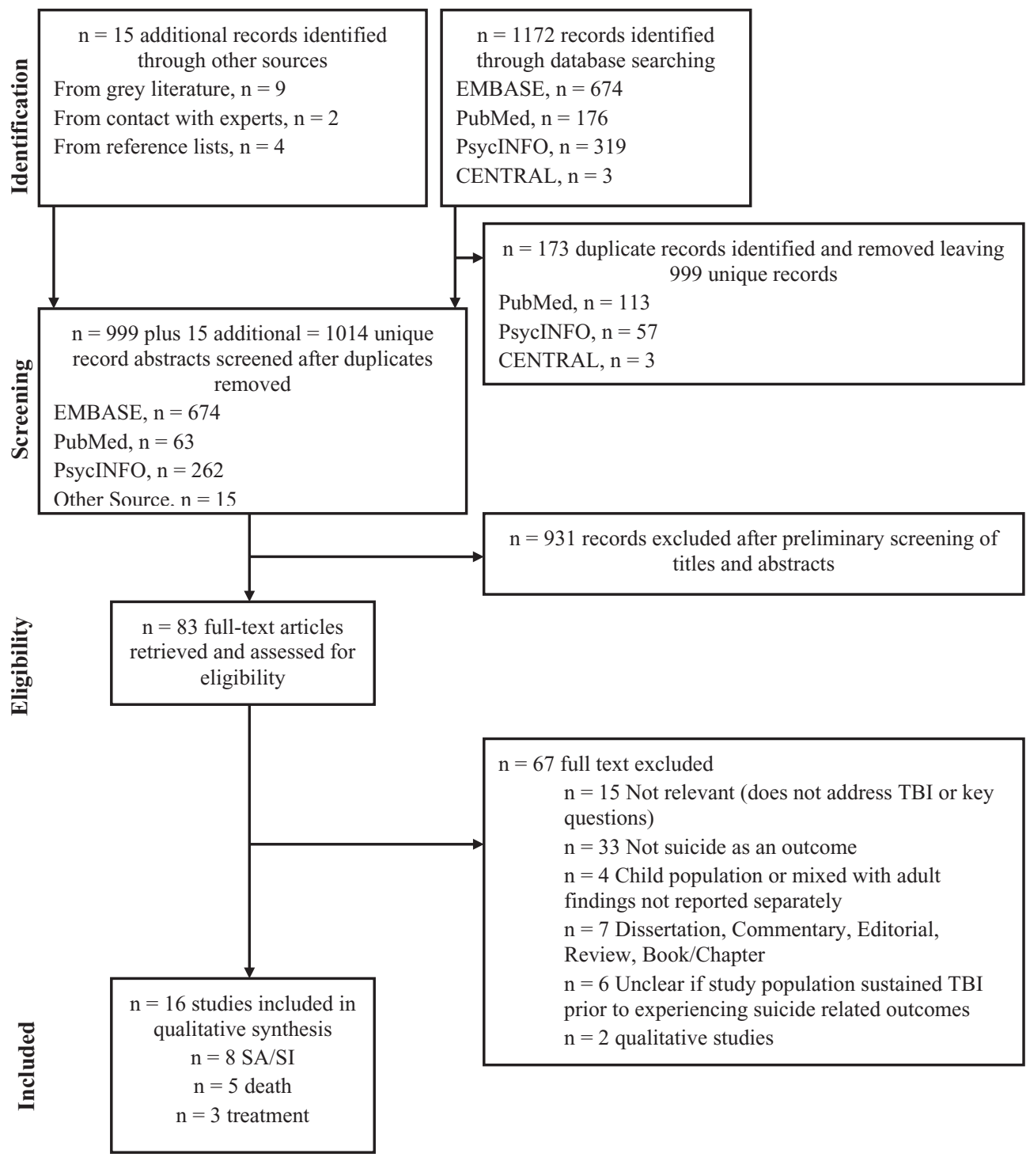

\section{FIGURE 1}

Literature flow diagram.

Gordon, 2011) and Veteran (Guitierrez et al., 2008) samples. The first study, rated as having a low risk bias, found a $28.3 \%$ rate of suicide ideation (item nine on the BDI-II; Beck, Steer, \& Brown, 1996) over the previous two-week period among a large sample of community-dwelling adults with TBI in the chronic phase post-injury. The second study (Gutierrez et al., 2008), rated as having a moderate risk of bias, found a prevalence rate of $72.7 \%$ among their sample of individuals who also had a history of post-injury psychiatric hospitalisation.

KQ1: Risk of Suicide Attempts and Suicidal Ideation after TBI

Five heterogeneous studies applied this question to a diverse range of issues (Table 5). Two of the five studies were rated as having a moderate risk of bias (Brenner et al., 2011a; Wood, Williams, \& Lewis, 2010), with the remainder rated as having a 
TABLE 2

Prevalence and Risk of Suicide After TBI

\begin{tabular}{|c|c|c|c|c|c|c|c|c|c|}
\hline Source & Design $^{a}$ & $\begin{array}{l}\text { Population/ } \\
\text { sample }\end{array}$ & $\begin{array}{l}\text { Study } \\
\text { admission }\end{array}$ & TBI & & $\begin{array}{l}\text { Reference } \\
\text { population }\end{array}$ & $\begin{array}{l}\text { Prevalence of } \\
\text { suicides }\end{array}$ & $\begin{array}{l}\text { SMR or OR } \\
(95 \% \mathrm{CI})\end{array}$ & Risk of bias (category of bias) ${ }^{b}$ \\
\hline $\begin{array}{l}\text { Brenner et al., } \\
2011 \mathrm{c} \\
\text { Veteran, United } \\
\text { States }\end{array}$ & $\begin{array}{l}\text { Retrospective } \\
\text { cohort }\end{array}$ & $\begin{array}{l}N=49,626 \\
\text { All VHA users } \\
\text { with TBI }\end{array}$ & $\begin{array}{l}2001-2006, \\
6 \text { years }\end{array}$ & $\begin{array}{l}\text { Concussion } \\
\text { Contusion/ } \\
\mathrm{TIH}\end{array}$ & $\begin{array}{l}12,159 \\
39,623\end{array}$ & $\begin{array}{l}5 \% \text { random } \\
\text { sample of VHA } \\
\text { users without TBI } \\
N=389,583\end{array}$ & $\begin{array}{l}105 \\
\text { observed }\end{array}$ & $\begin{array}{l}\text { All* } \\
1.55(1.24, \\
1.92) \\
\text { Mild**} \\
1.98 \text { (1.39, } \\
2.82) \\
\text { Mod-Sev } \\
1.34(1.09 \\
1.64)\end{array}$ & $\begin{array}{l}\text { Rating: low risk of bias } \\
\text { Outcome assessors not blinded } \\
\text { to exposure (DB) } \\
\text { Use of ICD-10 less accurate for } \\
\text { injuries in which medical } \\
\text { attention was not sought (DB) }\end{array}$ \\
\hline $\begin{array}{l}\text { Harrison-Felix } \\
\text { et al., } 2009 \\
\text { Civilian, United } \\
\text { States }\end{array}$ & $\begin{array}{l}\text { Retrospective } \\
\text { cohort }\end{array}$ & $\begin{array}{l}N=1678 \\
\text { Persons with } \\
\text { TBI admitted to } \\
\text { an adult } \\
\text { rehabilitation } \\
\text { hospital and } \\
\text { survived }>1 \\
\text { year }\end{array}$ & $\begin{array}{l}1961-2003 \\
40 \text { years }\end{array}$ & $\begin{array}{l}\text { Loss of } \\
\text { conscious- } \\
\text { ness } \\
\text { None } \\
1 \text { day } \\
2-7 \text { days } \\
8-129 \text { days }\end{array}$ & $\begin{array}{l}129 \\
495 \\
360 \\
568\end{array}$ & $\begin{array}{l}\text { Federal US } \\
\text { mortality rates } \\
\text { by age, sex and } \\
\text { race }\end{array}$ & $\begin{array}{l}10 \text { observed, } \\
3.39 \\
\text { expected }\end{array}$ & $\begin{array}{l}\text { Allc } \\
2.95(1.42, \\
5.43)\end{array}$ & $\begin{array}{l}\text { Rating: moderate risk of } \\
\text { bias } \\
\text { External comparison group not } \\
\text { selected based on TBI status } \\
\text { (SB \& CON) } \\
\text { Outcome assessors not blinded } \\
\text { to exposure (DB) } \\
\text { Cause of death unknown or } \\
\text { missing for } 12 \text { cases (AB) } \\
\text { Presence of TBI in reference } \\
\text { group (CON) }\end{array}$ \\
\hline $\begin{array}{l}\text { Himanen et al., } \\
2011 \\
\text { Civilian, } \\
\text { Finland }\end{array}$ & $\begin{array}{l}\text { Retrospective } \\
\text { cohort }\end{array}$ & $\begin{array}{l}N=192 \\
\text { All referrals for } \\
\text { neurological or } \\
\text { NP A'x at a } \\
\text { university } \\
\text { hospital }\end{array}$ & $\begin{array}{l}1950-1971, \\
24-30 \text { years }\end{array}$ & $\begin{array}{l}\text { Mild } \\
\text { Moderate } \\
\text { Severe } \\
\text { Very severe }\end{array}$ & $\begin{array}{l}65 \\
68 \\
53 \\
5\end{array}$ & $\begin{array}{l}\text { General } \\
\text { population }\end{array}$ & $\begin{array}{l}3 / 75 \text { deaths, } \\
4.2 \%\end{array}$ & NR & $\begin{array}{l}\text { Rating: moderate risk of } \\
\text { bias } \\
\text { External comparison group not } \\
\text { selected based on TBI status (SB } \\
\text { and CON) } \\
\text { Outcome assessors not blinded } \\
\text { to exposure (DB) } \\
\text { TBI severity not based on } \\
\text { standard criteria (DB) } \\
\text { Validity and reliability of data } \\
\text { source for suicide is unclear (DB) } \\
\text { Presence of TBI in reference } \\
\text { group (CON) }\end{array}$ \\
\hline
\end{tabular}


TABLE 2

Continued

\begin{tabular}{|c|c|c|c|c|c|c|c|c|c|}
\hline Source & Design $^{a}$ & $\begin{array}{l}\text { Population/ } \\
\text { sample }\end{array}$ & $\begin{array}{l}\text { Study } \\
\text { admission }\end{array}$ & $\mathrm{TBI}$ & & $\begin{array}{l}\text { Reference } \\
\text { population }\end{array}$ & $\begin{array}{l}\text { Prevalence of } \\
\text { suicides }\end{array}$ & $\begin{array}{l}\text { SMR or OR } \\
(95 \% \mathrm{CI})\end{array}$ & Risk of bias (category of bias) ${ }^{b}$ \\
\hline $\begin{array}{l}\text { Mainio et al., } \\
2007 \\
\text { Civilian, } \\
\text { Finland }\end{array}$ & $\begin{array}{l}\text { Cross- } \\
\text { sectional }\end{array}$ & $\begin{array}{l}N=1877 \\
\text { All general } \\
\text { population } \\
\text { suicides in } \\
\text { single province }\end{array}$ & $\begin{array}{l}1988-2004 \\
16 \text { years }\end{array}$ & $\begin{array}{l}\text { Concussion } \\
\text { Lesion }^{d}\end{array}$ & $\begin{array}{l}83 \\
20\end{array}$ & $\begin{array}{l}\text { Subset of } 1877 \\
\text { suicides with no } \\
\text { identified TBI }\end{array}$ & $\begin{array}{l}103 / 1877 \\
5.5 \%\end{array}$ & NA & $\begin{array}{l}\text { Rating: moderate risk of } \\
\text { bias } \\
\text { Assessors of TBI exposure not } \\
\text { blinded to suicide (DB) } \\
\text { TBI status was based on ICD-9 } \\
\text { codes for inpatient treatment or } \\
\text { hospitalisation only (DB) } \\
\text { mTBls likely underrepresented or } \\
\text { misclassified (CON) }\end{array}$ \\
\hline $\begin{array}{l}\text { Skopp et al., } \\
2012 \\
\text { Military } \\
\text { personnel, } \\
\text { United States }\end{array}$ & Case control & $\begin{array}{l}N=1764 \\
\text { All general } \\
\text { population } \\
\text { suicides in US } \\
\text { military active } \\
\text { service }\end{array}$ & $2001-2009$ & $\begin{array}{l}\text { Mild } \\
\text { Moderate } \\
\text { Severe } \\
\text { Unclassified }\end{array}$ & $\begin{array}{l}97 \\
25 \\
5 \\
2\end{array}$ & $\begin{array}{l}\text { Random } \\
\text { selection, } \\
\text { matched } 4: 1 \\
\text { ratio to cases by } \\
\text { service, gender, } \\
\text { race, age, date } \\
\text { of entry active } \\
\text { service, length of } \\
\text { military service }\end{array}$ & $\begin{array}{l}129 / 1764 \\
7.3 \%\end{array}$ & $\begin{array}{l}\text { Mild (OR) } \\
1.1(0.88 \\
1.42)\end{array}$ & $\begin{array}{l}\text { Rating: moderate risk of } \\
\text { bias } \\
\text { Assessors of TBI exposure not } \\
\text { blinded to case/ control status } \\
\text { (DB) } \\
\text { Use of ICD-10 less accurate for } \\
\text { injuries in which medical } \\
\text { attention was not sought (DB) } \\
\text { Risk for moderate to severe TBI } \\
\text { not reported due to limited } \\
\text { cases; only mTBI analysed and } \\
\text { reported (RB and PRE) } \\
\text { Differences in length of time } \\
\text { from injury to death not } \\
\text { addressed (CON) }\end{array}$ \\
\hline
\end{tabular}

SMR, Standardized Mortality Ratio; OR, Odds Ratio; Cl, Confidence Interval; VHA, Veterans Health Administration; TBI, Traumatic Brain Injury; TIH, Traumatic Intracranial Haemorrhage; Mod, Moderate; Sev, Severe; ICD-10, International Statistical Classification of Diseases-10; NP Áx, Neuropsychological Assessment; NR, Not Reported; NA, Not Applicable.

a Determined using the Taxonomy of Study Design Tool (Hartling et al., 2010).

${ }^{b}$ RTI Risk of Bias tool (Viswanathan \& Berkman, 2012); potential sources of bias include selection bias (SB), detection bias (DB), performance bias (PB), reporting bias (RB), attrition bias

$(A B)$, confounding (CON) and precision (PRE).

'SMR reported as statistically significant but $p$ value not provided.

dInjuries classified as lesions included cerebral contusion and intracranial haemorrhage.

${ }^{\star} p<.0001$, adjusted model. ${ }^{* *} p=.0002$, adjusted model. ${ }^{\dagger} p=.006$, adjusted model. 


\section{TABLE 3}

Prevalence of Suicide Attempts (SA) After TBI

\begin{tabular}{|c|c|c|c|c|c|c|c|c|c|}
\hline Source & Design $^{a}$ & Sample/setting & $\begin{array}{l}\text { Sample sex/ } \\
\text { age }\end{array}$ & TBI severity & & $\begin{array}{l}\text { SA source/time } \\
\text { frame }\end{array}$ & $\begin{array}{l}\text { Time-post } \\
\text { injury }\end{array}$ & $\begin{array}{l}\text { Prevalence of } \\
\text { SA }\end{array}$ & Risk of bias (category of bias) \\
\hline $\begin{array}{l}\text { Breshears et } \\
\text { al., } 2010 \\
\text { Veteran, United } \\
\text { States }\end{array}$ & $\begin{array}{l}\text { Retrospective } \\
\text { cross- } \\
\text { sectional }\end{array}$ & $\begin{array}{l}N=154 \\
\text { Archival data of } \\
\text { interdisciplinary } \\
\text { TBI team } \\
\text { evaluations, } \\
\text { recruit NA }\end{array}$ & $\begin{array}{l}149 M, 5 F \\
\text { Age } \\
M(S D)= \\
30.30 \\
(11.57)\end{array}$ & $\begin{array}{l}\text { Mild } 42 \\
\text { Mod } 44 \\
\text { Sev } 68\end{array}$ & $\begin{array}{l}27.3 \% \\
28.6 \% \\
62.4 \%\end{array}$ & $\begin{array}{l}\text { Medical record } \\
\text { review, clinical } \\
\text { determination of } \\
\text { presence of SA, } \\
\text { post-TBI }\end{array}$ & 14 yrs post & $7.1 \%$ & $\begin{array}{l}\text { Rating: moderate risk of } \\
\text { bias } \\
\text { Outcome assessors not blinded } \\
\text { to exposure (DB) } \\
\text { Use of keyword searches } \\
\text { instead of diagnostic codes to } \\
\text { classify SA (DB) } \\
\text { Limited to SA that occurred } \\
\text { within } 2 \text { years post diagnostic } \\
\text { evaluation (DB) }\end{array}$ \\
\hline $\begin{array}{l}\text { Gutierrez et al., } \\
2008 \\
\text { Veteran, United } \\
\text { States }\end{array}$ & $\begin{array}{l}\text { Retrospective } \\
\text { case-series }\end{array}$ & $\begin{array}{l}\mathrm{N}=22 \\
\text { Attended TBI } \\
\text { interdisciplinary } \\
\text { team, archival } \\
\text { data of all with } \\
\mathrm{H}^{\prime} \times \text { of IP } \\
\text { psychiatric } \\
\text { admission, } \\
\text { recruit NA }\end{array}$ & $\begin{array}{l}21 M, 1 F \\
M d n=51 \text { yrs } \\
\text { (range 38-65 } \\
\text { yrs) }\end{array}$ & $\begin{array}{l}\text { Mild } 1 \\
\text { Mod } 11 \\
\text { Sev } 10\end{array}$ & $\begin{array}{l}4.5 \% \\
50.0 \% \\
45.5 \%\end{array}$ & $\begin{array}{l}\text { SA documented } \\
\text { in psychiatric } \\
\text { discharge } \\
\text { summaries, } \\
\text { post-TBI }\end{array}$ & $\begin{array}{l}\text { Mdn = } 15 \\
y r s\end{array}$ & $27.3 \%$ & $\begin{array}{l}\text { Rating: moderate risk of } \\
\text { bias } \\
\text { Those whose hospitalisations } \\
\text { occurred prior to computerised } \\
\text { records were not included (SB) } \\
\text { Outcome assessors not blinded } \\
\text { to exposure (DB) } \\
\text { Validated measure of SI not } \\
\text { used (DB) } \\
\text { Data regarding SI limited to } \\
\text { hospital discharge records (DB) }\end{array}$ \\
\hline
\end{tabular}

TBI, Traumatic Brain Injury; Mod, Moderate; Sev, Severe; M, Male; F, Female; H'x, History; IP, Inpatient; M, Mean; Mdn, Median; NA, Not Applicable; SD, Standard deviation; yrs, years. a Determined using the Taxonomy of Study Design Tool (Hartling et al., 2010).

b RTI Risk of Bias tool (Viswanathan \& Berkman, 2012); potential sources of bias include selection bias (SB), detection bias (DB), performance bias (PB), reporting bias (RB), attrition bias $(\mathrm{AB})$, confounding $(\mathrm{CON})$, and precision (PRE). 
TABLE 4

Prevalence of Suicidal Ideation (SI) After TBI

\begin{tabular}{|c|c|c|c|c|c|c|c|c|c|}
\hline Source & Design $^{a}$ & Sample/setting & $\begin{array}{l}\text { Sample sex/ } \\
\text { age }\end{array}$ & Injury severity & & $\begin{array}{l}\text { Sl source/ time } \\
\text { frame }\end{array}$ & $\begin{array}{l}\text { Time-post } \\
\text { injury }\end{array}$ & $\begin{array}{l}\text { Prevalence } \\
\text { of SI }\end{array}$ & Risk of bias (category of bias) ${ }^{b}$ \\
\hline $\begin{array}{l}\text { Tsaousides } \\
\text { et al., } 2011 \\
\text { Civilian, United } \\
\text { States }\end{array}$ & $\begin{array}{l}\text { Retrospective } \\
\text { cross- } \\
\text { sectional }\end{array}$ & $\begin{array}{l}N=356 \\
\text { Community- } \\
\text { dwelling, } \\
\text { diverse sources }\end{array}$ & $\begin{array}{l}186 \mathrm{M}, 170 \mathrm{~F} \\
\text { Age } \\
M(S D)=44.5 \\
(15.2) \text { yrs }\end{array}$ & $\begin{array}{l}\text { Mild } \\
\text { Mod-Sev }\end{array}$ & $\begin{array}{l}37.6 \% \\
62.4 \%\end{array}$ & $\begin{array}{l}\text { Score } \geq 1 \text { on SI } \\
\text { item on BDI-II } \\
\text { last } 2 \text { weeks }\end{array}$ & $\begin{array}{l}M(S D)=5.9 \\
(9.2) \text { yrs }\end{array}$ & $28.3 \%$ & $\begin{array}{l}\text { Rating: low risk of bias } \\
\text { Outcome assessors not blinded } \\
\text { to exposure (DB) } \\
\text { Single-item measure of SI not } \\
\text { validated (DB) }\end{array}$ \\
\hline $\begin{array}{l}\text { Gutierrez et al., } \\
2008 \\
\text { Veteran, United } \\
\text { States }\end{array}$ & $\begin{array}{l}\text { Retrospective } \\
\text { case series }\end{array}$ & $\begin{array}{l}N=22 \\
\text { Attended TBI } \\
\text { interdisciplinary } \\
\text { team, archival } \\
\text { data of all with } \\
\mathrm{H}^{\prime} x \text { of IP } \\
\text { psychiatric } \\
\text { admission, } \\
\text { recruit NA }\end{array}$ & $\begin{array}{l}21 \mathrm{M}, 1 \mathrm{~F} \\
\text { Age } \\
\text { Mdn = 51 yrs } \\
\text { (range 38-65 } \\
\text { yrs) }\end{array}$ & $\begin{array}{l}\text { Mild } 1 \\
\text { Mod } 11 \\
\text { Sev } 10\end{array}$ & $\begin{array}{l}4.5 \% \\
50.0 \% \\
45.5 \%\end{array}$ & $\begin{array}{l}\text { Reference to } \\
\text { suicide ideation } \\
\text { in psychiatric } \\
\text { discharge } \\
\text { summaries, } \\
\text { post-TBI }\end{array}$ & $\begin{array}{l}\text { Mdn }=15 \\
\text { yrs }\end{array}$ & $72.7 \%$ & $\begin{array}{l}\text { Rating: moderate risk of } \\
\text { bias } \\
\text { Those whose hospitalisations } \\
\text { occurred prior to computerised } \\
\text { records were not included (SB) } \\
\text { Outcome assessors not blinded } \\
\text { to exposure (DB) } \\
\text { Validated measure of SI not } \\
\text { used (DB) } \\
\text { Data regarding SI limited to } \\
\text { hospital discharge records (DB) }\end{array}$ \\
\hline
\end{tabular}

TBI, Traumatic Brain Injury; Mod, Moderate; Sev, Severe; M, Male; F, Female; BDI-II, Beck Depression Inventory-II; M, Mean; SD, Standard deviation; Mdn, Median; H'x History; IP, Inpatient; NA, Not Applicable; yrs, years.

a Determined using the Taxonomy of Study Design Tool (Hartling et al., 2010).

${ }^{b}$ RTI Risk of Bias tool (Viswanathan \& Berkman, 2012); potential sources of bias include selection bias (SB), detection bias (DB), performance bias (PB), reporting bias (RB), attrition bias

$(A B)$, confounding (CON), and precision (PRE). 
TABLE 5

Risk of Suicide Attempts (SA) and/or Suicidal Ideation (SI) After TBI

\begin{tabular}{|c|c|c|c|c|c|c|c|c|}
\hline Source & Design $^{1}$ & Sample/setting & $\begin{array}{l}\text { Sample } \\
\text { sex/age }\end{array}$ & $\mathrm{TBI}$ & Suicidal behaviour & Analysis & $\begin{array}{l}\text { Test statistic/ } \\
\text { result }\end{array}$ & Risk of bias (category of bias) ${ }^{2}$ \\
\hline $\begin{array}{l}\text { Brenner et al., } \\
2011 a \\
\text { Veteran, United } \\
\text { States }\end{array}$ & Case-control & $\begin{array}{l}N=81 \\
\text { Veterans with } \\
\mathrm{H}^{\prime} \times \text { of } \mathrm{SA} \\
N=160 \\
\text { Veteran controls, } \\
\text { no } \mathrm{H}^{\prime} \times \mathrm{SA}, \\
\text { matched } 2: 1 \\
\text { ratio to cases by } \\
\text { age and gender }\end{array}$ & $\begin{array}{l}\text { All subjects } \\
200 M, 41 \mathrm{~F} \\
\text { Age } \\
M=48.0 \\
(11.0)\end{array}$ & $\begin{array}{l}\text { Naturally } \\
\text { occurring } \\
\text { TBI } \\
24 / 81 \\
\text { cases } \\
47 / 160 \\
\text { controls } \\
\text { TBI severity } \\
\text { NR }\end{array}$ & $\begin{array}{l}\text { Medical record review, } \\
\text { clinical determination } \\
\text { of presence of SA }\end{array}$ & $\begin{array}{l}\text { Logistic } \\
\text { Regression } \\
\text { Compare TBI } \\
\text { only, PTSD only } \\
\text { and TBI + PTSD } \\
\text { as predictors of } \\
\text { membership of } \\
\text { the SA group vs. } \\
\text { no SA group }\end{array}$ & $\begin{array}{l}\text { OR }(95 \% \mathrm{Cl}) \\
\mathrm{TBI} \text { only } \\
1.03(0.57 \\
1.86) \\
\mathrm{ns}\end{array}$ & $\begin{array}{l}\text { Rating: moderate risk of } \\
\text { bias } \\
\text { Controls selected from a larger } \\
\text { database of mental health clinic } \\
\text { users (SB) } \\
\text { Assessors of TBI exposure not } \\
\text { blinded to case/ control status } \\
\text { (DB) } \\
\text { Use of keyword searches } \\
\text { instead of diagnostic codes to } \\
\text { classify TBI and SA (DB) }\end{array}$ \\
\hline $\begin{array}{l}\text { Wood et al., } \\
2010 \\
\text { Civilian, United } \\
\text { Kingdom }\end{array}$ & $\begin{array}{l}\text { Prospective } \\
\text { cross- } \\
\text { sectional }\end{array}$ & $\begin{array}{l}N=90 \\
\text { Patients at a } \\
\text { university } \\
\text { head-injury } \\
\text { clinic } \\
\mathrm{N}=74 \\
\text { Healthy controls } \\
(\mathrm{HC}) \text { known to } \\
\text { the authors }\end{array}$ & $\begin{array}{l}\text { TBI } \\
68 M, 22 \mathrm{~F} \\
\text { Age inj } \\
M(S D)=34.8 \\
(15.3) \\
\mathrm{HC} \\
50 M, 24 \mathrm{~F} \\
\text { Age } \\
M(S D)= \\
36.89(16.09)\end{array}$ & $\begin{array}{l}\text { PTA } \\
M(S D)= \\
14.4(27.7) \\
\text { days } \\
\text { GCS } \\
M(S D)= \\
9.6(4.4)\end{array}$ & $\begin{array}{l}\text { Score } \geq 1 \text { on } \mathrm{SI} \text { item } \\
\text { on BDI-II, last } 2 \text { weeks }\end{array}$ & $\begin{array}{l}\text { Between groups } \\
\text { (TBI vs. HC) Chi } \\
\text { square }\end{array}$ & $\begin{array}{l}\mathrm{TBI} \\
35(33.3 \%) \\
\mathrm{HC} \\
1(1.4 \%) \\
\chi^{2}= \\
25.679 *\end{array}$ & $\begin{array}{l}\text { Rating: moderate risk of } \\
\text { bias } \\
\text { TBI and HC drawn from two } \\
\text { different populations (SB) } \\
\text { Outcome assessors not blinded } \\
\text { to exposure (DB) } \\
\text { Single-item measure of SI not } \\
\text { validated (DB) } \\
\text { Partially accounted for } \\
\text { confounding variables (CON) }\end{array}$ \\
\hline $\begin{array}{l}\text { Barnes et al., } \\
2012 \\
\text { Veteran, United } \\
\text { States }\end{array}$ & $\begin{array}{l}\text { Retrospective } \\
\text { cross- } \\
\text { sectional }\end{array}$ & $\begin{array}{l}N=92 \\
\text { Medical record } \\
\text { reviews of } \\
\text { consecutive } \\
\text { referrals for } \\
\text { outpatient } \\
\text { PTSD treatment, } \\
\text { recruit NA }\end{array}$ & $\begin{array}{l}92 M \\
\text { Age } \\
M(S D)= \\
30.3(8.2)\end{array}$ & $\begin{array}{l}46 / 92 \mathrm{H}^{\prime} \mathrm{x} \\
\text { comorbid } \\
\mathrm{mTBI}\end{array}$ & $\begin{array}{l}3 \text { single-item questions: } \\
\text { Thoughts about } \\
\text { death/killing self? } \\
\text { Ever intended to } \\
\text { commit suicide? } \\
\text { Ever attempted } \\
\text { suicide? }\end{array}$ & $\begin{array}{l}\text { Between groups } \\
\text { (PTSD vs. PTSD } \\
+ \text { mTBI) } \\
\text { univariate } \\
\text { analyses of items }\end{array}$ & $\begin{array}{l}\text { SI ns; no } \\
\text { statistical tests } \\
\text { of suicidal } \\
\text { intent or past } \\
\text { suicide } \\
\text { attempts } \\
\text { conducted } \\
\text { due to low } \\
\text { numbers }\end{array}$ & $\begin{array}{l}\text { Rating: high risk of bias } \\
\text { Unclear if criteria to classify } \\
\text { mTBI was also used to deter- } \\
\text { mine absence of mTBI (SB) } \\
\text { Unclear if lifetime history of } \\
\text { mTBI assessed in control group } \\
\text { (DB) } \\
\text { Outcome assessors not blinded } \\
\text { to exposure (DB) } \\
\text { Single-item measure of SI not } \\
\text { validated (DB) } \\
\text { Important confounders partially } \\
\text { addressed (CON) } \\
\text { Not powered to detect small } \\
\text { effects (PRE) }\end{array}$ \\
\hline
\end{tabular}


TABLE 5

Continued

\begin{tabular}{|c|c|c|c|c|c|c|c|c|}
\hline Source & Design $^{1}$ & Sample/setting & $\begin{array}{l}\text { Sample } \\
\text { sex/age }\end{array}$ & $\mathrm{TBI}$ & Suicidal behaviour & Analysis & $\begin{array}{l}\text { Test statistic/ } \\
\text { result }\end{array}$ & Risk of bias (category of bias) ${ }^{2}$ \\
\hline $\begin{array}{l}\text { Romesser et al., } \\
2011 \\
\text { Veteran, United } \\
\text { States }\end{array}$ & $\begin{array}{l}\text { Retrospective } \\
\text { cross- } \\
\text { sectional }\end{array}$ & $\begin{array}{l}N=144 \\
\text { Medical record } \\
\text { reviews of } \\
\text { voluntary PTSD } \\
\text { evaluations with } \\
\text { clinician } \\
\text { confirmed PTSD, } \\
\text { recruit NA }\end{array}$ & $\begin{array}{l}144 M \\
\text { Age < } 30 \\
81(56 \%)\end{array}$ & $\begin{array}{l}62 / 144 \\
\mathrm{H}^{\prime} x \\
\text { comorbid } \\
\text { concussion }\end{array}$ & $\begin{array}{l}\text { Scale for Suicide } \\
\text { ldeation, } 4 / 5 \text { items } \\
\text { tested } \\
\text { Thoughts of } \\
\text { self-harm/death } \\
\text { Desire to make attempt } \\
\text { Frequency suicide } \\
\text { thoughts } \\
\text { Control over suicide } \\
\text { thoughts }\end{array}$ & $\begin{array}{l}\text { Between groups } \\
\text { (PTSD vs. PTSD } \\
+ \text { concussion) } \\
\text { univariate } \\
\text { analyses of items }\end{array}$ & $\begin{array}{l}\text { All four } \\
\text { analyses ns }\end{array}$ & $\begin{array}{l}\text { Rating: high risk of bias } \\
\text { Variable criteria to determine } \\
\text { absence of TBI (SB) } \\
\text { Item analysis of SSI not valid } \\
\text { (DB) } \\
\text { Sum for SSI screening items NR } \\
\text { (RB) } \\
\text { Important confounding variables } \\
\text { not accounted for in analyses } \\
\text { (CON) } \\
\text { Did not control for multiple } \\
\text { comparisons (PRE) }\end{array}$ \\
\hline $\begin{array}{l}\text { Yurgelun-Todd } \\
\text { et al., } 2011 \\
\text { Veteran, United } \\
\text { States }\end{array}$ & $\begin{array}{l}\text { Cross- } \\
\text { sectional }\end{array}$ & $\begin{array}{l}\mathrm{N}=32 \text { (15 } \\
\text { Veterans with } \\
\mathrm{TBI}, 17 \mathrm{HC} \\
\text { from the } \\
\text { community) }\end{array}$ & $\begin{array}{l}32 M \\
\text { Age } M(S D) \\
\text { TBI } 34.9 \text { (9.7) } \\
\text { HC } 34.0 \\
(10.6)\end{array}$ & $\begin{array}{l}\text { Mild } 11 \\
\text { Moderate- } \\
\text { Severe: } \\
4\end{array}$ & $\begin{array}{l}\text { Composite score for } \\
\text { current SI utilizing } \\
\text { information from the } \\
\text { Columbia Suicide } \\
\text { Severity Rating Scale, } \\
\text { the SCID-I/P, and } 3 \\
\text { items on the Trauma } \\
\text { Severity Inventory (TSI) }\end{array}$ & Descriptive & $\begin{array}{l}\text { SI current } \\
\text { All TBI } \\
M=1.4 \\
\text { (range 0-5) } \\
\text { SI most } \\
\text { severe } \\
\text { All TBI } \\
M=4.07 \\
\text { (range 0-9) }\end{array}$ & $\begin{array}{l}\text { Rating: moderate risk of } \\
\text { bias } \\
\text { TBI and HC controls drawn from } \\
\text { two different populations (SB) } \\
\text { Outcome assessors not blinded } \\
\text { to exposure (DB) } \\
\text { Composite score of SI not } \\
\text { validated (DB) } \\
\text { SI not reported for HC (RB) }\end{array}$ \\
\hline
\end{tabular}

TBI, Traumatic Brain Injury; M, Male; F, Female; NR, Not Reported; OR, Odds Ratio; M, Mean; SD, Standard deviation; H'x, History; IP, Inpatient; PTSD, Post-traumatic Stress Disorder; PTA, Post-traumatic Amnesia; GCS, Glasgow Coma Scale; BDI-II, Beck Depression Inventory-II; mTBI, mild traumatic brain injury; SCID-I/P, Structured Clinical Interview for DSM-IV (Patient Version); NA, Not Applicable; ns, not significant; yrs, years.

a Determined using the Taxonomy of Study Design Tool (Hartling et al., 2010).

${ }^{b}$ RTI Risk of Bias tool (Viswanathan \& Berkman, 2012); potential sources of bias include selection bias (SB), detection bias (DB), performance bias (PB), reporting bias (RB), attrition bias $(A B)$, confounding $(C O N)$ and precision (PRE)

${ }^{*} p=.0005$ 
TABLE 6

Treatment Studies

\begin{tabular}{|c|c|c|c|c|c|c|c|c|}
\hline Source & Design $^{a}$ & Sample, setting & Sex, age & $\begin{array}{l}\text { Injury } \\
\text { severity/time } \\
\text { post-injury }\end{array}$ & $\begin{array}{l}\text { Primary outcome, } \\
\text { intervention }\end{array}$ & $\begin{array}{l}\text { Measure of } \\
\text { suicide ideation } \\
\text { (SI) }\end{array}$ & $\begin{array}{l}\text { Attrition, } T^{\prime} x \\
\text { Outcome }\end{array}$ & Risk of Bias (category of bias) ${ }^{b}$ \\
\hline $\begin{array}{l}\text { Simpson et al., } \\
2011 \\
\text { Civilian, } \\
\text { Australia }\end{array}$ & $\mathrm{RCT}$ & $\begin{array}{l}N=17 \\
\text { Brain injury } \\
\text { community } \\
\text { rehabilitation } \\
\text { service }\end{array}$ & $\begin{array}{l}16 M, 1 F \\
\text { Age } \\
M(S D)=39.7 \\
(19)\end{array}$ & $\begin{array}{l}\text { Sev } 17 \\
M(S D) \text { yrs } \\
6.3(6.8) \mathrm{T}^{\prime} \\
\text { X7.6 (4.6) } \\
\text { waitlist }\end{array}$ & $\begin{array}{l}\text { Hopelessness, } \\
\text { Beck Hopelessness } \\
\text { Scale } \\
\text { 20-h manualised } \\
\text { Group CBT } \\
\text { programme, } 20 \\
\text { hours }\end{array}$ & $\begin{array}{l}\text { Secondary } \\
\text { outcome } \\
\text { Beck Scale for } \\
\text { Suicide Ideation } \\
\text { range 0-38 }\end{array}$ & $\begin{array}{l}16 \text { complete } \\
T^{\prime} x \\
T^{\prime} x \text { gp } n=8 \\
M(S D) \\
7.8(10.7) \\
\text { Pre-T'x } \\
5.1(8.9) \\
\text { Post-T'x } \\
\text { NS repeated } \\
\text { measures } \\
\text { analysis }\end{array}$ & $\begin{array}{l}\text { Rating: low risk of bias } \\
\text { PEDro Rating: } 8 / 10 \\
\text { Therapists and patients not } \\
\text { blinded to treatment condition } \\
\text { (DB) } \\
\text { Small sample limited power to } \\
\text { detect treatment effect for SI } \\
\text { (PREC) }\end{array}$ \\
\hline $\begin{array}{l}\text { Rapoport et al, } \\
2008 \\
\text { Civilian, } \\
\text { Canada }\end{array}$ & $\begin{array}{l}\text { Before-After } \\
\text { Study }\end{array}$ & $\begin{array}{l}N=65 \\
\text { Mild-moderate } \\
\text { TBI clinic, } \\
\text { tertiary trauma } \\
\text { care centre }\end{array}$ & $\begin{array}{l}38 M, 27 F \\
\text { Age } \\
M(S D)= \\
39.7(19)\end{array}$ & $\begin{array}{l}\text { Mild } 33 \\
\text { Mod-Sev 32, } \\
\text { time } \\
\text { post-injury } \\
\text { NR }\end{array}$ & $\begin{array}{l}\text { Depression } \\
\text { First wave, } n=29 \\
\text { fixed dose } \\
\text { citalopram, } 20 \\
\text { mg/day, } 6 \text { weeks } \\
\text { Second wave, } n= \\
36 \\
\text { flexible dose } \\
\text { citalopram, } \\
\text { Start } 20 \mathrm{mg} / \text { day, } \\
\text { titrating to max. } 50 \\
\text { mg/day, } 10 \text { wks }\end{array}$ & $\begin{array}{l}\text { Secondary } \\
\text { outcome } \\
\text { suicide ideation } \\
\text { item, Hamilton } \\
\text { Depression } \\
\text { Scale, range NR }\end{array}$ & $\begin{array}{l}54 \text { complete } 6 \\
\text { wks of } T^{\prime} x \text {, } \\
\text { Specific } \\
\text { suicide } \\
\text { ideation } \\
\text { values NR }\end{array}$ & $\begin{array}{l}\text { Rating: unclear risk of bias } \\
\text { Outcome assessors not blinded to } \\
\text { intervention (DB) } \\
\text { Single-item measure of SI not } \\
\text { validated (DB) } \\
\text { Numeric values for SI not } \\
\text { reported (RB) } \\
\text { Impact of loss to follow-up not } \\
\text { assessed (AB) } \\
\text { Partially accounted for important } \\
\text { confounders (CON) }\end{array}$ \\
\hline $\begin{array}{l}\text { Rees \& Bellon, } \\
2007 \\
\text { Civilian, } \\
\text { Australia }\end{array}$ & $\begin{array}{l}\text { Before-After } \\
\text { Study }\end{array}$ & $\begin{array}{l}\mathrm{N}=20, \\
\text { Brain injury } \\
\text { community } \\
\text { rehabilitation } \\
\text { service, } 20 \% \text { of } \\
\text { admitted clients } \\
\text { over previous } 10 \\
\text { yrs }\end{array}$ & $\begin{array}{l}10 M, 10 F \\
\text { Age } \\
M(S D)= \\
31.2(11.2)\end{array}$ & $\begin{array}{l}\text { Post } \\
\text { Concussion } \\
\text { Syndrome, } \\
\text { GCS 13-15 } \\
\text { Ranchos Los } \\
\text { Amigos scale } \\
5-7, \\
\text { time } \\
\text { post-injury } \\
\text { NR }\end{array}$ & $\begin{array}{l}\text { Post Concussion } \\
\text { Syndrome symptoms } \\
\text { (NSI) } \\
\text { Individual } \\
\text { client-centred } \\
\text { counselling }+ \text { CBT, } \\
\text { minimum } 62 \text { h over } 2 \\
\text { yrs }\end{array}$ & $\begin{array}{l}\text { Secondary } \\
\text { outcome } \\
\text { Suicide ideation } \\
\text { item, Beck } \\
\text { Depression } \\
\text { Inventory-ll, } \\
\text { range NR }\end{array}$ & $\begin{array}{l}20 \text { complete } \\
T^{\prime} x \\
\text { Yr } 10.8 \pm \\
0.6 \\
\text { Yr } 20.3 \pm \\
0.6, \\
\text { Paired t-tests } t \\
=3.9^{*}\end{array}$ & $\begin{array}{l}\text { Rating: high risk of bias } \\
\text { Unclear if eligibility criteria was } \\
\text { uniformly applied across patients } \\
\text { (SB) } \\
\text { Outcome assessors not blinded to } \\
\text { intervention (DB) } \\
\text { Single item measure of SI not } \\
\text { validated (DB) } \\
\text { Important aspects of the } \\
\text { intervention not described (PB) }\end{array}$ \\
\hline
\end{tabular}




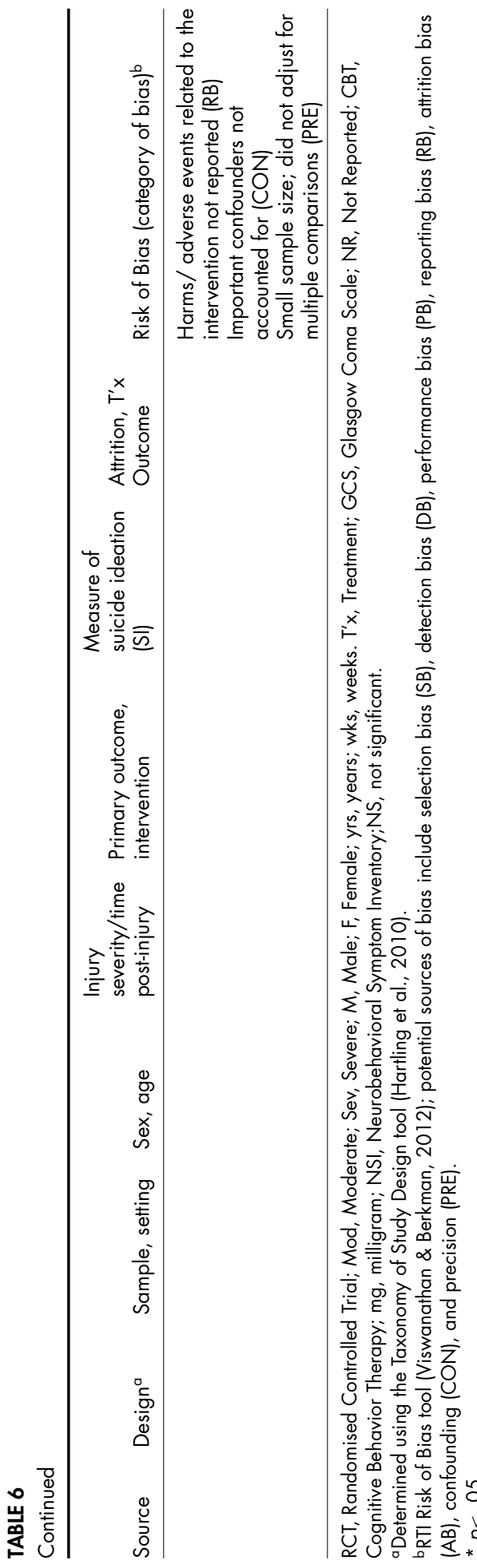

high risk of bias. In a controlled prospective crosssectional suicide-specific study, Wood et al. (2010) reported a $33.3 \%$ rate of suicide ideation (item nine on the BDI-II; Beck et al., 1996) among 90 patients of mixed injury severity. This rate was significantly greater than that reported by a matched comparison group of healthy controls.

Three studies examined the relationship between post-traumatic stress disorder (PTSD), TBI or mild TBI and suicide risk in US Veteran samples. In an archival case-controlled study (moderate risk of bias), Brenner et al. (2011a) examined a sample of Veterans with a history of suicide attempts, and compared them to a matched control group with no such history. The naturally occurring proportion of Veterans with TBI in both groups was high, virtually identical at approximately $30 \%$. In a series of logistic regressions, the relative association of PTSD versus TBI was tested, finding that while a history of PTSD was associated with an increased risk for having a history of suicide attempts, a similar relationship was not found for TBI. Two other studies (Barnes, Walter, \& Chard, 2012; Romesser et al., 2011; both high risk of bias) examined whether a comorbid mild TBI among Veterans with PTSD played an additive role, increasing the likelihood of suicidal behaviours, compared to Veterans with PTSD alone. Both studies reported non-significant results. The aim of the final study (Yurgelun-Todd et al., 2011) was to examine the relationship between frontal white matter systems and measures of impulsivity and suicidality in Veterans with TBI. Descriptive data regarding SI were also reported. Risk of bias was moderate.

KQ2: Interventions for Reducing Suiciderelated Outcomes in Persons with TBI

Three treatment studies (two psychosocial, one pharmacological) were identified in which suicide ideation was an outcome (Table 6). However, suicide ideation was not the primary target of any of the three treatments. One study specifically aimed to reduce suicide risk by treating hopelessness. It was the only study which tested an a priori hypothesis pertaining to suicide ideation. The study's primary hypothesis was that a psychological treatment would reduce hopelessness after severe TBI (primary outcome). The study also hypothesised that this reduction in hopelessness would be associated with a related reduction in suicide ideation (a secondary outcome), due to the intercorrelation between the two clinical phenomena. This hypothesis was tested in a RCT (Simpson, Tate, Whiting, \& Cotter, 2011; low risk of bias). Although the suicide ideation scores decreased from pre- to post-intervention among the treatment group while 
scores of the waiting list group members increased (suggesting increased ideation), these trends were non-significant.

The other two studies were rated as an unclear risk (Rapoport et al., 2008) and high risk of bias (Rees \& Bellon, 2007). In both studies, changes in suicidal ideation were incidental to the primary treatment target (depression, Rapoport et al., 2008; post-concussional symptoms, Rees \& Bellon, 2007) and were reported along with other symptoms on depression measures.

\section{Discussion}

The World Health Organisation asserts that suicide is preventable (World Health Organisation, 2012). One application of this principle at an organisational level is to ensure that sufficient knowledge regarding those at risk is available to guide resource allocation (e.g., research, clinical). The current review identified 16 studies that addressed the issue of suicide after TBI, of which three had a low risk of bias. These three studies investigated different indicators of self-directed violence among those with TBI as their primary aim. Two of the studies addressed the associations between TBI and suicide deaths (Brenner et al., 2011c) or suicidal ideation (Tsaousides et al., 2011). The third was an RCT of a suicide prevention treatment (Simpson et al., 2011). Nine of the remaining studies were determined to have a moderate risk of bias, with the final four being rated as having high or unclear levels of bias.

The review found new robust evidence of the association between TBI and elevated risk of suicide. The report by Brenner et al. (2011c) was the first suicide-specific study among Veterans with TBI since Achte, Lonnqvist and Hillbom's (1971) seminal work reporting on Second World War Finish Veterans. This elevated rate among Veterans was also reported in the meta-analysis by Harris and Barraclough (1997) and complements the findings from the civilian population study by Teasdale and Engberg (2001). The elevated rate of suicide was also found in a single-centre study investigating mortality among a rehabilitation cohort (Harrison-Felix et al., 2009; moderate risk of bias).

These two positive findings contribute to the debate about whether there is an elevated risk of suicide after TBI. Some studies have not found a significant association (e.g., HarrisonFelix, Whiteneck, DeVivo, Hammond, \& Jha, 2004; Lewin et al., 1979; Shavelle et al., 2001). However, Harrison-Felix et al. (2004) have raised the issue that findings based on small numbers of suicides (e.g., one or two) need to be viewed with caution because the corresponding standard- ised mortality ratios are too unstable. Given the low base rate of suicide (typically $1-2$ per 10,000 ), studies investigating death by suicide need to be adequately powered. As such, large-scale studies are required to address meaningfully this question. Interestingly, the large-scale studies conducted to date have all found evidence of increased suicide risk.

In addition to issues of statistical power, selection of an appropriate comparison group is one of the most critical aspects in the design of a cohort study. Understanding the true effect of TBI on suicidal outcomes requires selection of a comparison group that is similar to the exposed TBI cohort on all important characteristics except for TBI status. Of the three retrospective cohort studies, only one (Brenner et al., 2011c) used a comparison group of persons without a history of TBI that were selected from the same source population as those with TBI, while the other two (Harrison-Felix et al., 2009; Himanen et al., 2011) relied on external comparison groups (i.e., general population rates) to examine the effect of TBI on overall mortality or death by suicide. Although convenient, use of external comparison groups limits understanding of the true effects of TBI on suicide outcomes. Even if the general population is chosen to be as similar as possible to the TBI cohort in relation to basic demographic and geographic variables, presence of TBI and other unidentified risk factors in the comparison group may lead to either an underestimation or overestimation of its true effect.

Despite the upsurge of research activity in the area of TBI and suicide in the past 5 years, there continues to be a dearth of quality research examining the prevalence of suicidal ideation and attempts among those with TBI. Most notably, since the first review (Simpson \& Tate, 2007), no new population-level studies investigating ideation or attempts among those with TBI were identified. At the level of clinical studies, the $28.3 \%$ prevalence rate of suicide ideation found by Tsaousides et al. (2011; low risk of bias) was similar to rates reported in the three studies identified in the 2007 review. Together, the four studies all highlight significant levels of suicide ideation present in the chronic phase post-TBI. The one study employing a non-brain-damaged (healthy) control group found that the rate of suicide ideation among people with TBI was significantly higher (Wood et al., 2010; moderate risk of bias).

A new development in this review was the emergence of studies that examined whether the increased risk of suicide identified in TBI samples/populations could be detected among the general population or other clinical groups (i.e., PTSD). Two studies examined suicide deaths 
(Skopp et al., 2012) and suicide attempts (Brenner et al., 2011a) among active duty and Veteran populations. Using a case-control methodology (suicidal behaviour present versus absent), they investigated whether a greater proportion of cases in the suicide-present groups had a history of TBI. Neither of these studies found that TBI was a significant risk factor. Similarly, the two studies which examined whether the presence of co-morbid TBI in Veterans with PTSD added to the level of suicidal ideation (Barnes et al., 2012; Romesser et al., 2011) were also non-significant. Potential reasons for these non-significant findings include study design, the low-base rate of suicidal behaviour, small sample sizes, and/or dependence on chart review for data regarding exposure (TBI) and outcomes (suicidal thoughts or behaviours).

The review identified one RCT (Simpson et al., 2011), a psychological treatment for hopelessness among people with severe TBI. Although the intervention did not directly target a suicidal behaviour, hopelessness is one of the strongest predictors of suicide and is closely correlated with suicide ideation. Despite this advance, the treatment still requires replication in larger trials of high-quality design.

Overall, the studies displaying moderate or high risk of bias varied significantly in terms of methodology and assessment of TBI. Many did not use psychometrically sound tools to measure outcomes of interest. Few studies adjusted the results for the most important potential confounding factors (i.e., age and gender) contributing to significant sources of bias. The variability noted in terms of both exposure and case ascertainment of TBI and controls further calls into question the strength of existing evidence. Moreover, few new studies were identified wherein suicidal ideation, attempts or death were examined as primary outcomes in TBI-specific samples designed to address the association between TBI exposure and suicidal outcomes. Some of the studies reviewed were notable for their poor reporting of methods and procedures. This lack of transparency made it difficult to rate bias and/or to determine the strength of the existing evidence pertaining to Key Questions 1 and 2. As such, researchers are encouraged to follow reporting guidelines specific to their study design (e.g., STROBE (von Elm et al., 2008) for observational studies).

Some limitations of this review should be considered in interpreting the results. Three additional studies addressing TBI and suicide were identified; however, they did not meet review inclusion criteria (McMillan \& Teasdale, 2007; McMillan, Teasdale, Weir, \& Stewart, 2011; Ventura et al., 2010). In all three, findings regarding those younger than age 18 were mixed with adult data; thereby precluding separate evaluation regarding the results of interest. An inherent limitation of such high specificity is the possibility of excluding quality studies that do not fit within the predetermined parameters, but may otherwise be important contributions to the body of evidence. Additionally, it is important to note that two of the authors of the current review were also authors on 6 of the 16 papers reviewed. As such, various procedures were implemented throughout the systematic review process to reduce biases and ensure objectivity when critically appraising studies. Furthermore, individuals were not primarily responsible for review of the articles on which they were authors.

Findings from this review highlight the need for further research to establish the prevalence of SI and SA among those with a history of TBI. Understanding the true prevalence of these outcomes in TBI populations will support validation of suiciderelated outcome measures, and ultimately allow for accurate assessment of change in interventional trials. Moreover, knowledge regarding the prevalence of SI and SA will highlight the resources needed to care for members of this population who, according to the data, are at risk of dying by suicide.

Although the question of increased risk of suicide-related outcomes following TBI was addressed in the current review, specific factors that contribute to increased risk of these outcomes were not examined. Future systematic reviews are also needed to clarify the existing evidence regarding risk and protective factors, as well as warning signs for suicidal thoughts and behaviours among those with TBI. In addition, no reviews have been completed in the aim of establishing evidence-based assessment strategies regarding suicide risk.

Research examining the impact of TBI severity on suicide risk is another area that warrants further investigation. Although studies have shown an increased risk of suicide across all levels of TBI severity, the extent to which TBI severity influences the pathway to suicidal behaviour or the trajectory of risk has yet to be examined extensively. Along these lines, research examining neurobiological correlates and markers of suicide-related outcome among TBI survivors (e.g., YurgelunTodd et al., 2011), and the influence of TBI severity on such markers, represent an emerging area of research that holds great potential for advancing the field.

\section{References}

Achte, K.A., Lonnqvist, J., \& Hillbom, E. (1971). Suicides following war brain injuries. Acta Psychiatrica Scandinavica. Supplementum, 225, 1-94. 
Anstey, K., Butterworth, P., Jorm, A.F., Chistensen, H., Rodgers, B., \& Windsor, T.D. (2004). A population survey found an association between self-reports of traumatic brain injury and increased psychiatric symptoms. Journal of Clinical Epidemiology, 57, 1202-1209.

Barnes, S.M., Walter, K.H., \& Chard, K.M. (2012). Does a history of mild traumatic brain injury increase suicide risk in Veterans with PTSD? Rehabilitation Psychology, 57(1), 18-26.

Beck, A.T., Steer, R.A., \& Brown, G.K. (1996). Manual for the Beck Depression Inventory-II. San Antonio, TX: Psychological Corporation.

Brenner, L.A., Betthauser, L.M., Homaifar, B.Y., Villarreal, E., Harwood, J.E., Staves, P.J., ... Huggins, J.A. (2011a). Posttraumatic stress disorder, traumatic brain injury, and suicide attempt history among Veterans receiving mental health services. Suicide amd Life Threatening Behavior, 41, 416423.

Brenner, L.A., Breshears, R.E., Betthauser, L.M., Bellon, K.K., Holman, E., Harwood, J.E., ... Nagamoto, H.T. (2011b). Implementation of a suicide nomenclature within two VA healthcare settings. Journal of Clinical Psychology in Medical Settings, 18(2), 116-128.

Brenner, L.A., Ignacio, R.V., \& Blow, F.C. (2011c). Suicide and traumatic brain injury among individuals seeking Veterans Health Administration services. Journal of Head Trauma Rehabilitation, 26(4), 257264.

Brenner, L.A., Vanderploeg, R.D., \& Terrio, H. (2009). Assessment and diagnosis of mild traumatic brain injury, posttraumatic stress disorder, and other polytrauma conditions: Burden of adversity hypothesis. Rehabilitation Psychology, 54, 239-246.

Breshears, R.E., Brenner, L.A., Harwood, J.E.F., \& Gutierrez, P.M. (2010). Predicting suicidal behavior in Veterans with traumatic brain injury: The utility of the Personality Assessment Inventory. Journal of Personality Assessment, 92, 349-355.

Carroll, L.J., Cassidy, J.D., Holm, L., Kraus, J., \& Coronado, V.G. (2004). Methodological issues and research recommendations for mild traumatic brain injury: The WHO Collaborating Centre Task Force on mild traumatic brain injury [Supplemental material]. Journal of Rehabilitation Medicine, 43, 113 125.

Centers for Disease Control and Prevention. (2012). Suicide mortality. National Vital Statistics System. Retrieved from http://www.cdc.gov/nchs/pressroom/ states/SUICIDE_STATE_2010.pdf

deMorton, N.A. (2009). The PEDro scale is a valid measure of the methodological quality of clinical trials: A demographic study. Australian Journal of Physiotherapy, 55, 129-133.

Gutierrez, P.M., Brenner, L.A., \& Huggins, J.A. (2008). A preliminary investigation of suicidality in psychiatrically hospitalized Veterans with traumatic brain injury. Archives of Suicide Research, 12(4), 336343.
Harris, C., \& Barraclough, B. (1997). Suicide as an outcome for mental disorders. British Journal of Psychiatry, 170, 205-228.

Harrison-Felix, C., Whiteneck, G., DeVivo, M., Hammond, F.M., \& Jha, A. (2004). Mortality following rehabilitation in the Traumatic Brain Injury Model Systems of Care. NeuroRehabilitation, 19, 45-54.

Harrison-Felix, C., Whiteneck, G., DeVivo, M., Hammond, F.M., \& Jha, A. (2006). Causes of death following 1 year postinjury among individuals with traumatic brain injury. Journal of Head Trauma Rehabilitation, 21, 22-33.

Harrison-Felix, C.L., Whiteneck, G.G., Jha, A., DeVivo, M.J., Hammond, F.M., \& Hart, D.M. (2009). Mortality over four decades after traumatic brain injury rehabilitation: A retrospective cohort study. Archives of Physical Medicine and Rehabilitation, 90(9), 1506-1513.

Hartling, L., Bond, K., Harvey, K., Santaguida, P.L., Viswananthan, M., \& Dryden, D.M. (2010). Methods Research Report: Developing and testing a tool for the classification of study designs in systematic reviews of interventions and exposures (Agency for Healthcare Research and Quality Publication No. 11-EHC-007). Retrieved from http://effectivehealth care.ahrq.gov/

Heiskanen, O., \& Sipponen, P. (1970). Prognosis of severe brain injury. Acta Neurologica Scandinavica, 46(3), 343-348.

Himanen, L., Portin, R., Hamalainen, P., Hurme, S., Hiekkanen, H., \& Tenovuo, O. (2011). Risk factors for reduced survival after traumatic brain injury: A 30-year follow-up study. Brain Injury, 25(5), 443452.

Lewin, W., Marshall, T.F., \& Roberts, A.H. (1979). Longterm outcome after severe head injury. British Medical Journal, 2, 1533-1538.

Liberati, A., Altman, D.G., Tetzlaff, J., Mulrow, C., Gøtzsche, P.C., Ioannidis, J.P., ... Moher, D. (2009). The PRISMA statement for reporting systematic reviews and meta-analyses of studies that evaluate health care interventions: Explanation and elaboration. Journal of Clinical Epidemiology, 62(10), e1e34.

Macedo, L.G., Elkins, M.R., Maher, C.G., Moseley, A.M., Herbert, R.D., \& Sherrington, C. (2010). There was evidence of convergent and construct validity of Physiotherapy Evidence Database quality scale for physiotherapy trials. Journal of Clinical Epidemiology, 63, 920-925.

Maher, C.G., Sherrington, C., Herbert, R.D., Moseley, A.M., \& Elkins, M. (2003). Reliability of the PEDro scale for rating quality of randomized controlled trials. Physical Therapy, 83, 713-721.

Mainio, A., Kyllonen, T., Viilo, K., Hakko, H., Sarkioja, T., \& Rasanen, P. (2007). Traumatic brain injury, psychiatric disorders and suicide: A population-based study of suicide victims during the years 1988-2004 in Northern Finland. Brain Injury, 21, 851-855. 
McMillan, T.M., \& Teasdale, G.M. (2007). Death rate is increased for at least 7 years after head injury: A prospective study. Brain, 130(10), 25202527.

McMillan, T.M., Teasdale, G.M., Weir, C., \& Stewart, E. (2011). Death after head injury: The 13 year outcome of a case-control study. Journal of Neurology, Neurosurgery, and Psychiatry, 82, 931-935.

Moher, D., Liberati, A., Tetzlaff, J., Altman, D.G., \& The PRISMA Group. (2010). Preferred reporting items for systematic reviews and meta-analyses: The PRISMA statement. International Journal of Surgery, 8, 336-341.

NICE. (2012). Self-harm: Longer-term management (National Clinical Guideline Number 133). Retrieved from http://www.nice.org.uk/nicemedia/live/ 13619/57179/57179.pdf

O'Carroll, P.W., Berman, A.L., Maris, R.W., Moscicky, E.K., Tanney, B.L., \& Silverman, M.M. (1996). Beyond the Tower of Babel: A nomenclature for suicidology. Suicide and Life Threatening Behavior, 26, 237-252.

Rapoport, M.J., Chan, F., Lanctot, K., Herrmann, N., McCullagh, S., \& Feinstein, A. (2008). An openlabel study of citalopram for major depression following traumatic brain injury. Journal of Psychopharmacology, 22(8), 860-864.

Rees, R.J., \& Bellon, M.L. (2007). Post concussion syndrome ebb and flow: Longitudinal effects and management. NeuroRehabilitation, 22, 229-242.

Reeves, B.C., Deeks, J.J., Higgins, J.P.T., \& Wells, G.A. (2008). Chapter 13: Including non-randomized studies. In J.P.T. Higgins \& S. Green S (Eds.), Cochrane handbook for systematic reviews of interventions (Version 5.0.1). Retrieved from www.cochranehandbook.org

Reeves, R.R., \& Brister, J.C. (2009). Traumatic brain injury and suicide. In L. Sher \& A. Vilens (Eds.), Terror and suicide (pp. 105-114). New York: Nova Science Publishers.

Reeves, R.R., \& Laizer, J.T. (2012). Traumatic brain injury and suicide. Journal of Psychosocial Nursing and Mental Health Services, 50(3), 32-38.

Romesser, J., Shen, S., Reblin, M., Kircher, J., Allen, S., Roberts, T., ... Marchand, W.R. (2011). A preliminary study of the effect of a diagnosis of concussion on PTSD symptoms and other psychiatric variables at the time of treatment seeking among Veterans. Military Medicine, 176(3), 246-252.

Russell, W.R. (1951). Disability caused by brain wounds; A review of 1,166 cases. Journal of Neurology, Neurosurgery, and Psychiatry, 14(1), 35-39.

Shavelle, R.M., Strauss, D., Whyte, J., Day, S.M., \& Yu, Y.L. (2001). Long term causes of death after traumatic brain injury. American Journal of Physical Medicine and Rehabilitation, 80(7), 510-516.

Sherrington, C., Herbert, R.D., Maher, C.G., \& Moseley, A.M. (2000). PEDro: A database of randomized trials and systematic reviews in physiotherapy. Manual Therapy, 5, 223-226.
Silver, J.M., Kramer, R., Greenwald, S., \& Weissman, M. (2001). The association between head injuries and psychiatric disorders: Findings from the New Haven NIMH Epidemiologic Catchment Area Study. Brain Injury, 15, 935-945.

Simpson, G., \& Brenner, L.A. (2011). Perspectives on suicide and traumatic brain injury. Journal of Head Trauma and Rehabilitation, 26(4), 241-243.

Simpson, G., \& Tate, R. (2002). Suicidality after traumatic brain injury: Demographic, injury and clinical correlates. Psychological Medicine, 32(4), 687-697.

Simpson, G.K., \& Tate, R.L. (2005) Clinical features of suicide attempts after traumatic brain injury. Journal of Nervous and Mental Disease, 19, 680685.

Simpson, G., \& Tate, R. (2007). Suicidality in people surviving a traumatic brain injury: Prevalence, risk factors and implications for clinical management. Brain Injury, 21(21), 1335-1351.

Simpson, G.K., \& Tate, R.L. (2009). Suicidality and suicide prevention among war Veterans with traumatic brain injury. In L. Sher \& A. Vilens (Eds.), Suicide in the military (pp. 161-182). New York, NY: Nova Science Publishers.

Simpson, G.K., Tate, R.L., Whiting, D.L., \& Cotter, R.E. (2011). Suicide prevention after traumatic brain injury: A randomized controlled trial of a program for the psychological treatment of hopelessness. Journal of Head Trauma Rehabilitation, 26(4), 290300.

Simpson, G.K., Winstanley, J., \& Bertapelle, T. (2003). Evaluation of a suicide prevention training workshop for staff working in the field of traumatic brain injury. Journal of Head Trauma Rehabilitation, 18, 445456.

Skopp, N.A., Trofimovich, L., Grimes, J., Oetjen-Gerdes, L., \& Gahm, G.A. (2012). Relations between suicide and traumatic brain injury, psychiatric diagnoses, and relationship problems, Active Component, U.S. Armed Forces, 2001-2009. Medical Surveillance Monthly Report, 19(2), 7-11.

Tate, R.L., Perdices, M., McDonald, S., Togher, L., Moseley, A., \& Winders, K., ... Savage, S. (2004). Development of a database of rehabilitation therapies for the psychological consequences of acquired brain impairment. Neuropsychological Rehabilitation, 14, 517-534.

Teasdale, T.W., \& Engberg, A.W. (2001). Suicide after traumatic brain injury: a population study. Journal of Neurology, Neurosurgery, and Psychiatry, 71, 436440.

Tsaousides, T., Cantor, J.B., \& Gordon, W.A. (2011). Suicidal ideation following traumatic brain injury: Prevalence rates and correlates of adults living in the community. Journal of Head Trauma Rehabilitation, 26(4), 265-275.

Ventura, T., Harrison-Felix, C., Carlson, N., Diguiseppi, C., Gabella, B., Brown, A., ... Whiteneck, G. (2010). Mortality after discharge from acute care hospitalization with traumatic brain 
injury: A population-based study. Archives of Physical Medicine and Rehabilitation, 91, 20-29.

Viswanathan, M., Ansari, M.T., Berkman, N.D., Chang, S., Hartling, L., McPheeters, L.M., ... Treadwell, J.R. (2012). Assessing the risk of bias of individual studies in systematic reviews of health care interventions. Agency for Healthcare Research and Quality Methods Guide for Comparative Effectiveness Reviews (AHRQ Publication No. 12-EHC047EF). Retrieved from http://www.effectivehealthcare. ahrq.gov/

Viswanathan, M., \& Berkman, N.D. (2012). Development of the RTI item bank on risk of bias and precision of observational studies. Journal of Clinical Epidemiology, 65(2), 163-178.

von Elm, E., Altman, D.G., Egger, M., Pocock, S.J., Gøtzsche, P.C., \& Vandenbroucke, J.P., STROBE Initiative. (2008). The strengthening the reporting of observational studies in epidemiology (STROBE) statement: guidelines for reporting observational studies. Journal of Clinical Epidemiology, 61(4), 344-349.

Wasserman, L., Shaw, T., Vu, M., Ko, C., Bollegala, D., \& Bhalerao, S. (2008). An overview of traumatic brain injury and suicide. Brain Injury, 22(11), 811-819.

Wood, R.L.L., Williams, C., \& Lewis, R. (2010). Role of alexithymia in suicide ideation after traumatic brain injury. Journal of the International Neuropsychological Society, 16, 1108-1114.

World Health Organisation. (2012). Public health action for the prevention of suicides. Retrieved from http:// apps.who.int/iris/bitstream/10665/75166/1/ 9789241503570_eng.pdf

Yurgelun-Todd, D.A., Bueler, C.E., McGlade, E., Churchwell, J., Brenner, L.A., \& Lopez-Larson, M. (2011). Neuroimaging correlates of traumatic brain injury and suicidal behavior. Journal of Head Trauma Rehabilitation, 26(4), 276-289. 